\title{
The new political economy of higher education: between distributional conflicts and discursive stratification
}

\author{
Tobias Schulze-Cleven ${ }^{1}$ - Tilman Reitz ${ }^{2}$. Jens Maesse ${ }^{3}$. \\ Johannes Angermuller 4
}

Published online: 1 March 2017

(C) Springer Science+Business Media Dordrecht 2017

\begin{abstract}
The higher education sector has been undergoing a far-reaching institutional re-orientation during the past two decades. Many adjustments appear to have strengthened the role of competition in the governance of higher education, but the character of the sector's emerging new political economy has frequently remained unclear. Serving as the introduction for the special issue, this article makes the case for a multidimensional strategy to probe higher education's competitive transformation. In terms of conceptualizing the major empirical shifts, we argue for analyzing three core phenomena: varieties of academic capitalism, the discursive construction of inequality, and the transformation of hierarchies in competitive settings. With respect to theoretical tools, we emphasize the complementary contributions of institutional, class-oriented, and discourse analytical approaches. As this introduction elaborates and the contributions to the special issue demonstrate, critical dialog among different analytical traditions over the interpretation of change is crucial for improving established understandings. Arguably, it is essential
\end{abstract}

Tilman Reitz

tilman.reitz@uni-jena.de

Tobias Schulze-Cleven

tschulzecleven@work.rutgers.edu

Jens Maesse

jensmaesse@gmx.de

Johannes Angermuller

j.angermuller@warwick.ac.uk

1 School of Management and Labor Relations, Rutgers University, New Brunswick, NJ 08901, USA

2 Institut für Soziologie, Universität Jena, Carl-Zeiss-Str. 2, 07743 Jena, Germany

3 Institut für Soziologie, Justus-Liebig-Universität, Karl-Glöckner-Str. 21E, 35394 Gießen, Germany

4 Centre for Applied Linguistics, University of Warwick, Coventry CV4 7AL, UK 
for clarifying the respective roles of capitalist power and hierarchical rule in the construction of the sector's new order.

Keywords Academic capitalism · Non-monetary competition · Neo-feudal hierarchies · Distributional conflict $\cdot$ Discursive stratification

The continuing expansion of higher education has produced policy challenges and conflicts about the allocation of resources. ${ }^{1}$ As the numbers of students and faculty have ballooned, financial and competitive pressures have followed. From South Africa to the UK, students and graduates wrestle with rising tuition costs and educational loans, frequently taking their protests to the streets. At the same time, many higher education institutions struggle to keep their budgets balanced, and from Latin America to the US for-profit providers have entered the sector, often selling programs of dubious quality for high fees. Junior scholars and adjunct faculty in many countries have opposed precarious work and employment conditions. Researchers complain that they face incentives to engage in superficial - or even fraudulentpractices to increase their citation counts and successfully acquire grants. Colleges and universities with less-successful faculty experience funding cuts, which sometimes threaten the institutions' most basic capacities to fulfill their missions. Yet, as increasing pressures transform - and often endanger - teaching and research, higher education has become evermore important for the social distribution of resources, power, and recognition.

Most of the current problems in the higher education sector are driven or mediated by diverse forms of competition. The multidisciplinary contributions in this special issue provide new analytical tools to understand the competitive transformation of higher education in different national, institutional, and disciplinary contexts. Three core phenomena will be examined for this purpose - varieties of academic capitalism, the discursive construction of inequality in higher education, and the persistence or (re-)emergence of hierarchies in competitive settings. The theoretical perspectives applied to these phenomena provide complementary analytical leverage: while institutional approaches can account for national varieties of academic capitalism, classoriented theories shed light on sedimented hierarchies and dynamics of power and domination. Moreover, discourse analytical methodologies help reveal the symbolic dimension of inequality in higher education.

With this framework, we challenge hegemonic discourses about the current transformation of higher education. Policymakers' discursive tropes - from the needs of dynamic "knowledge economies" to the benefits of "excellence" - tend to distract from the distributional conflicts and power dynamics in the sector. At the same time, contemporary research in higher education studies remains policy-oriented, descriptive, and undertheorized. In much writing on the evolution of national higher education systems, transnational forces and interdependencies receive too little attention. We contend that much stronger comparative frameworks are needed to understand the changing role of higher education as the sector struggles to maintain common (and potentially global) standards of quality in the face of steep institutional inequalities, and in an environment governed by the concentration of private wealth.

Geographically, the articles in this special issue focus on North America and Western Europe. While the main arguments advanced in this introduction and the theoretical perspectives discussed

\footnotetext{
${ }^{1}$ To underline the collaborative nature of this special issue, we reversed the alphabetical order of the guest editors' names for the introduction.
} 
in the issue are colored by this empirical concentration, the volume aims to analyze developments of global relevance. Many contributions refer to the US as a global model, and special attention is given to Germany and France as Europe's most populous countries. These cases represent paradigmatic approaches to academic governance, and they reveal important differences between market- and state-centered models, specific types of hierarchy and autonomy, as well as institutional frameworks of competition in higher education.

This introductory essay lays out the central motivation and the scope of the theoretical commitments that are shared across the different articles in the special issue. It briefly outlines the contributions' specific concerns and highlights the lines of theoretical debate between them. We proceed in four steps. First, we present the main reasons for choosing the proposed theoretical perspective. Second, we review recent waves of change in higher education - from marketization and increased competition to renewed hierarchies - to identify the range of phenomena that our special issue addresses. Third, we discuss the main analytical approaches assembled in this volume, notably studies of institutional change, neo-Marxism, and discourse theories. In the fourth step, we reflect upon the complementary nature of these approaches by highlighting important lines of contention and outlining a common research agenda.

\section{Academic capitalism, non-monetary competition, and neo-feudal hierarchies}

The concept of "academic capitalism" (Slaughter and Leslie 1997; Slaughter and Rhoades 2004) continues to provide an important rationale for marketization, growing managerial governance, and increasing competitive pressure. However, just as related ideas like the "entrepreneurial," "enterprise," or "market university," academic capitalism can only partially explain the complex social processes within and beyond new academic markets. In contrast to regular price-based markets, the quasi-markets and manifold competitions for prestige that have spread across the academy do not rely on obvious (and often not even on monetary) mechanisms of demand and supply. In many cases, institutions are not geared toward financial profit. Moreover, public and private expenditures are strongly interwoven: For instance, public funds have strongly underwritten the increasing prominence of for-profit institutions in the US (Douglass 2012; Mettler 2014; Eaton et al. 2016). For these reasons, some scholars have questioned whether classical notions of political economy can be applied to the current academic transformation (Marginson 2006; Rhoades and Slaughter 2006). Others have proposed focusing on the public functions of universities (Rhoten and Calhoun 2011), such as providing accessible infrastructures of knowledge and a high level of education. This special issue builds on these perspectives, exploring the shifting role of the state, new forms of institutionalized competition and control, and the academy's changing contribution to facilitating private appropriation of rents in knowledge capitalism.

A prominent emphasis in the analysis will be to demonstrate the importance of the symbolic and discursive dimensions of change to better understand higher education's new political economy, whether one is interested in the micro-political dynamics among academics (Angermuller 2013), the performative effects of rankings (Espeland and Sauder 2007), or political struggles over the role of academic expertise in the globalized political economy (Sum and Jessop 2013; Maesse 2015). To account for these factors, research must analyze processes of non-monetary competition. Money is not the only "currency" in scientific and educational fields, since competition among academics also revolves around "symbolic goods" (Bourdieu 1984), like prestige, recognition, or distinction. Such symbolic goods are valued because disciplinary communities and the broader public have come to see them as representing unique expertise or intellectual achievements. 
Two sets of theories provide promising leads for shedding light on the discursive construction of these goods' value and meaning. A first camp of fertile inquiry includes both the microsociological practice theories from the sociology of science (Latour and Woolgar 1979; Knorr Cetina 1999) and Foucauldian analyses of higher education in terms of "power knowledge" (Ball 1990; Rose 1996; Peters et al. 2009; Angermuller 2015). Breaking with the prioritization of economic struggles and/or institutional effects in the sociological traditions of Bourdieu, Weber, or Marx, many post-structuralist approaches emphasize historical contingency and the shifting character of the dispositif of power-knowledge (Maesse and Hamann 2016).

The "sociology of valuation and evaluation" (Lamont 2012) is a second line of inquiry that helps uncover processes of discursive competition, especially the rise of evaluations, quantitative performance measures, and ordinal rankings of individuals and institutions. Research has highlighted the unintended, negative effects of increasing competition in academic quality management. For instance, scholars have argued that citation indexing has not only been very selective in measuring research performance (Münch 2013, pp. 149-152), it might also hinder scientific progress through triggering narrow research strategies among scholars in pursuit of professional success (Rogge 2015, pp. 209f; Fang et al. 2012). In addition, studies have found peer review processes, another important governance instrument, to suffer from weak reliability (Cicchetti 1991; Reinhart 2012, pp. 57-59). Other studies have explored how instruments used for judging and measuring quality can nevertheless generate trust in distributive decisions (Reinhart 2012), establish objectified patterns of reputation (Münch 2016), and cultivate discipline-specific standards of fairness (Lamont 2009).

Some scholars have attempted to employ tools of practice theory and post-structuralism in the sociology of evaluation. Notable examples are the analysis of "rankings and reactivity" by Espeland and Sauder (2007; see also Sauder and Espeland 2009) and Richard Münch's studies on the social construction of academic excellence (e.g., Münch 2013; see also Hamann 2016). Yet, more theoretical synthesis is needed to effectively explore the origins and functions of academic performance measurement and evaluation. Moving toward this goal requires complementing micro-political analysis with reflection on macro-level distributional conflict (Schulze-Cleven 2017).

One focal point for such analyses should be the persistence and transformation of hierarchies within and between institutions of higher education, driven by both marketization or by non-monetary competition. These hierarchies - and, in certain cases, academic or economic oligarchies - play important roles in the new structures of competition. In many cases, moves toward competition and markets have strengthened the hegemony of the most successful American universities - Harvard, Princeton, Yale, Stanford, and Berkeley. For instance, universities' ability to file and market patents (which allow them to benefit from the commercialization of research) has paid off almost exclusively for elite institutions (Powell et al. 2007). Global rankings, moreover, have added to the reputations of elite institutions in particular. This includes traditional sites of excellence in Europe such as Cambridge, Oxford, and ETH Zurich, which continue to occupy prominent places among universities worldwide. Similarly, with respect to professional status hierarchies, globally renowned research professors tend to benefit from excellent facilities and conditions, perks that are often inconceivable at non-elite colleges, provincial universities or universities of applied sciences.

Efforts abound to move upwards within these hierarchies. More and more universities in Europe have been strategically striving for excellence, and national governments are supporting their competition with diverse excellence programs. During this reorientation, the devices used to measure academic quality have become important tools for administrative decisions about 
funds, positions, and the unequal distribution of teaching and research time among scholars. As a major consequence, however, existing hierarchies tend to be formalized and stabilized rather than loosened. According to some authors, managerial reforms in the USA and the Bologna Process in Europa have reduced academic autonomy (Slaughter and Rhoades 2004; SerranoVelarde 2015). And while the expanded role of peer reviews in publication markets and competitions for project funding has arguably empowered the academic profession against outside influence (Musselin 2013), it has also tended to strengthen the most powerful section of the professoriate. In sum, the ongoing re-structuring of academic relations of dependence and loyalty (as portrayed in Bourdieu 1984) appears to not only produce free-market dynamics but also to give rise to neo-feudal systems of power relations.

We introduce the paradigm of neo-feudalism to higher education studies in the hope that future scholarship can build on this foundation. In recent discussions of social inequality in Germany, the concepts of re-feudalization and neo-feudalism have gained some prominence (Neckel 2013; Zinn 2015). An analysis of changes in higher education along these conceptual lines could be helpful for understanding stratifications and power relations in the sector in many respects. Centrally, the neo-feudal lens shows how academic hierarchies are maintained through loyalties and alliances, through group privilege, and through the public representation of institutional prestige. ${ }^{2}$ Moreover, broader functions of the sector include "feudal" elements, such as para-statist networks of (corporate and academic) power centers (Mathies and Slaughter 2013), a caste-like reproduction of inequalities (Rivera 2015), and an economy of knowledge rents (Drahos and Braithwaite 2002). Various intellectual traditions can speak to the hierarchical power relations highlighted by the concept of neo-feudalism. For instance, Bourdieu's theories of "fractions" of the academic class, with their different patterns of reproduction and relationships to the ruling class, have recently been reemployed in empirical studies of professors and academic functionaries (Möller 2015; Graf 2015). Another crucial line of studying academic hierarchies includes neo-Weberian approaches to power and inequality. Here, the objective is to explore how the organizational dynamics of power among goal-oriented and strategic actors contribute to institutional forms of dealing with conflicts (Clark 1983; Gumport 2007).

This special issue implements these theoretical concerns through critical dialog among contributions from different disciplinary traditions. Rather than presenting one coherent reading of higher education's competitive makeover (which would necessarily be limited in the face of contemporary processes' complexity), the intention is to highlight the relative importance and interplay of political, discursive, and hierarchical dimensions of competition in the sector today. Focusing on the political nature of new academic markets allows exploration of how competitive settings are constructed, including their state-sanctioned nature. These considerations also help account for the distributional effects of particular institutional designs and identify the groups that benefit from political strategies. When considering the role of institutions in conditioning the processing and resolution of distributional conflicts (Thelen 2014), scholars can theorize how academic capitalism has differed between diverse economies and welfare regimes, conditioned by path dependencies and public authorities' political-economic strategies.

A discursive lens helps clarify the micro-politics behind the construction of meaning (Angermuller et al. 2014). Productive areas of inquiry include clarifying the media's role in structuring competition and uncovering the tensions in political discourse, such as

$\overline{2}$ This was Habermas's central point when he coined the term "re-feudalization" (Habermas 1962/1989), originally referring to media corporations. 
between political emphases on academics' "freedom" in global markets and the very real constraints that academic workers experience under the inequalities created by public policies. Critical discourse-oriented analyses explore how higher education has both increasingly been the object of governmental power technologies and played a crucial role in expanding the post-industrial "reserve army" of highly educated market participants. Moreover, this scholarship shows how global discourses, such as those about university rankings, connect the fate of members of the new academic (or academically trained) proletariat across different regions of the world.

In terms of hierarchies, the issue's interdisciplinary dialog also speaks to potential (functional) causes for and (systemic) limits to both discursive construction and political alternatives. In this respect, it seems crucial to understand how (and why) even mass and universal higher education (Trow 1974) tends to reproduce academic and social elites. Classanalytical accounts can speak to how far inequality is a hidden goal of contemporary reform. Moreover, it is important to ask how academic stratification might support the accumulation of wealth in contemporary knowledge capitalism. The ubiquitous evaluations of knowledge can be interpreted as a necessary feature of capitalist knowledge economies (Marginson 2008), and state-arranged competitions might facilitate the transformation of knowledge into a "fictitious commodity" (Jessop 2007). As the next sections show, the disciplinary plurality and analytical complementary of the articles in this issue are not only useful for uncovering the complex processes of transformation, they also reveal more unity than is evident at first.

\section{Phenomenology of change: marketization, performance measurement, and stratification}

The following trends are of particular importance among the social and political changes that have shaped the new political economy of higher education: (a) marketization; (b) non-monetary competition framed by an expansion of evaluations and performance measurements; and (c) the perspective of hierarchies as features of social, institutional, and symbolic stratification.

a) Marketization. Conservative or "neoliberal" policies in the US and the UK created and strengthened connections between the higher education sector and the broader market economy. In the US, legislation between the early 1980s and the 2000s reinforced intellectual property laws, supported business-university cooperation, and boosted the scope for research to generate profits (Berman 2012). At the same time, cuts in public funding increased pressure on colleges and universities to turn to tuition fees, donations, and returns on endowments to raise revenue. The Bayh-Dole Act of 1980 in the US, and the British government's introduction of tuition fees in 1998 (with successive increases in caps until the last major reform in 2011) mark early and later milestones in these policy shifts. In the budgets of American public research universities, the share of state appropriations fell by nearly half, while the share of tuition feesfrequently supported by federal loans and grants - nearly doubled between 2003 and 2012 (American Academy of Arts and Sciences 2016, p. 9).

One may, therefore, speak of a "financialization of higher education" in the US (Eaton et al. 2016). Sources of income and spending strategies in the sector have become increasingly dominated by financial mechanisms: universities' borrowing and investment based on endowments, student loans and interest payments, and profits from commercial higher education. 
Across these areas, the shares of financial (as opposed to other types of) costs and benefits per institution and student have multiplied since the late 1970s. Between 2003 and 2012, the "combined real costs from interests for institutional debt, operating margins at for-profits, and interests paid for student loans more than doubled" (Eaton et al. 2016, p. 2), while these "rising finance costs far surpassed increased financial returns" (Eaton et al. 2016, p. 23f.) from endowments and other sources. While financialization has also gathered strength in other countries like the UK and the Netherlands (McGettigan 2013; Engelen et al. 2014), the degrees of financialization have so far remained strongly country-specific in scope.

With respect to economically oriented managerial staff increasing their power over faculty, there also exist few universal trends. For instance, while policy makers in France and Germany have also tried to implement managerialist programs, the outcomes of these attempts have been mixed and do not always support the idea of a turn toward the market in higher education. After some subnational states in Germany introduced tuition fees in the early 2000s, they ended up revoking them after fierce opposition from students. In France, the main aim of recent university reforms has been to merge higher education institutions into fewer and bigger structures. When it comes to the provision of full-fee places for international students, it is not the US but the UK that leads the world, and Canada and Australia also perform strongly.

b) Indicator-based evaluations. Another core feature of neoliberal visions for governing higher education is the use of scales to measure research performance and (to a lesser extent) teaching quality. Such scales rely on highly diverse data on citation counts, research grants, and scientists' or students' judgments. Rankings often compress the heterogeneous data into one or very few dimensions. Evermore, rankings are being produced, and they have become very prominent in public discourse during recent years.

If one assumes a family resemblance between the diverse instruments used for evaluation and presumes at least some common tendencies in their different national and disciplinary contexts, one can identify a few key turning points in the development of governance through indicator-based evaluations. In 1975, the Institute for Scientific Information (ISI) introduced the impact factor as a measure of an article's importance when it published its first Journal Citation Report (Fleck 2013, p. 334). At about the same time, an intensifying discussion on peer reviews reflected their increasing importance in US research funding (Hornbostel et al. 2008). Three decades later, in 2003, Shanghai Jiao Tong University issued its first global university ranking; in 2004, the Times Higher Education Supplement followed suit with the World University Rankings. These international comparisons of entire institutions added a universal layer to existing country- or subject-specific rankings, such as the ranking of American law schools published by the U.S. News \& World Report (Espeland and Sauder 2007). The effects of these instruments - or their different "functions" for competition - have been widely discussed (see, e.g., Marginson and van der Wende 2007; Hazelkorn 2011) and are reflected in several contributions in this volume. Because the interpretation of rankings is connected to policies, debates, and categorizations in different academic contexts, complex results are to be expected.

Rankings and indexing often directly shape the distribution of economic resources in the academic field - including government spending - and they also affect reputations, which in turn determine the attractiveness of particular institutions for researchers, students, and donors - particularly the wealthiest students and donors. The new regime of evaluations, impact, and rankings therefore represents an economy that is equally material and discursive.

The functional linkages that most visibly connect the distribution of financial resources and the distribution of professional recognition are the disbursement of grants based on peer review and 
institutional governance through performance indicators. The latter is a particularly poignant example of competition-based state spending or New Public Management in academia. From the Research Assessment Exercise (1998-2008) and the Research Excellence Framework (since 2014) in the UK to excellence programs in Germany, France, and other countries, standardized output indicators are used as the basis for the distribution of resources. Functioning as an institutionalized Matthew effect (i.e., the further accumulation of resources among those that are already well-resourced), this academic version of "quasi-markets" has become the main distributive mechanism in some cases. In others (notably in Germany), the move toward contingent funding has been the preferred way for governments to spread a spirit of "entrepreneurialism" and increase "productivity." Thus, market discourses go hand in hand with meritocratic myths. In spite of all market rhetoric, however, a central function of competition-based spending is to justify the unequal distribution of public resources. When American public funders turned to peer review as a tool for grant making in the 1960s and 1970s, this change in approach was designed, not least, to ensure "scientists' accountability to tax payers" (Biagioli 2002, p. 123). It remains to be seen how researchers and research institutions today interpret their responsibilities to make efficient and effective use of public funds.

c) Stratification. In any case, both individuals and organizations compete under the premise that some of them are more equal than others. Recent trends toward hierarchization in the higher education sector can be traced in the organization of academic life as well as in the social consequences of higher education. In the academy, the trend is characterized by increasing distance between different types of institutions, particularly in terms of their annual revenues and their capital stocks (or endowments), but also in measured research "performance." While the American academy had long been paradigmatic for a highly polarized resource distribution, differences in wealth - as well as prestige and power-have grown significantly over the past two decades. As Meyer and Zhou show in this volume, the wealthiest American universities and colleges continue to benefit from the advantages of their endowments; and even among the richest institutions, wealth has become further concentrated. And research success follows the money. The contemporary distribution of research at US universities is strongly polarized (a phenomenon analyzed by Wieczorek, Beyer and Münch in this issue), with a separation between relatively autonomous, highly visible, elite departments at big research universities and a concentration of dependent, applied research outside these institutions. Similar hierarchies can be seen in the differing income levels of teaching and research staff employed by American institutions. Variation in pay is increasing between institutions, disciplines, and tasks - particularly at the upper management levels - and becoming increasingly disassociated from academic ranks and even positions in professional networks.

In terms of higher education's social consequences, shifts in stratification might even be more significant, and the reproduction of social hierarchies (and oligarchies) via higher education has gained new relevance. Several studies on the US (Rivera 2015) have recently pointed out that neoliberal policies have reversed the country's long-running trend toward greater inclusiveness and higher education's moderately positive effect on social mobility. Increases in mobility came to an end during the 1970s and have since been reversed (Carnevale and Strohl 2010; Mettler 2014). Although the role of American higher education in sustaining social inequalities may not be as paradigmatic for global trends as the country's stratification among institutions and academic careers has arguably been, the threat of renewed polarization between the educated and noneducated parts of society remains pressing - and will likely grow more so as IT tools replace even skilled tasks in the looming "second machine age" (Brynjolfsson and MacAfee 2014). 
This special issue explores such changes within the academy and in the academy's relationship with society through different conceptual lenses. While the accumulation of wealth and cultural capital within narrow social circles can be viewed as a regular (and politically sanctioned) "capitalist" process, its evaluative infrastructures can be seen as a new technology of discursively mediated power. Additionally, the post-traditional stability of privileged groups and institutions can also be taken as a sign of "neo-feudal" tendencies. Sometimes even similar developments invite different explanations, and the approaches used by the authors in this volume at times lead them to divergent conclusions. Yet, their findings are in many cases complementary, and they cooperate in the effort to transcend established paradigms, such as those of new institutionalism, sociologies of evaluation, or simple applications of theories formulated by Marx, Foucault, or Bourdieu. The following outline of the contributions should help to identify the main theoretical strands, tensions, and points of convergence.

\section{Analytical approaches: between distributional conflicts and discursive stratification}

To situate the articles in this special issue with regard to debates in social theory, we have grouped the different approaches into two camps, each under a heading that highlights the main object of analysis. The contributions of the first group are primarily concerned with the policies and mechanisms of resource distribution. Some of the articles use methodologies from political science, institutionalist studies, and comparative public and social policy analyses. Other texts in this group, informed by Marxist and Weberian social theory, make theoretical claims about the systemic dynamics of knowledge capitalism, neo-feudalism, or even "feudalized capitalism" in and around academia. The second group of articles employs constructivist, discourse theoretical, and interpretive approaches to academic stratification. The main theoretical points of reference range from Foucault to Ricoeur. We have grouped these contributions together under the heading of discursive stratification.

\section{Policies and mechanisms of resource distribution}

The most obvious way to link the different dimensions of higher educations' new political economy is to study different policies in the sector and probe their respective outcomes. This strategy often involves distinguishing between two different kinds of agents: collective, institutionally empowered actors, such as governments, university management, business groups, foundations, professional associations, and academic labor unions, who might exercise a considerable degree of consequential agency vis-à-vis broader structures, and individual actors - students, parents, members of research and teaching staff, and potential employers of graduates. The behavior of both collective and individual agents is shaped by institutionalized rules and arrangements, which differ historically and regionally, and are the focus of political decisions and interventions. Institutional structures can sustain very different arrangements, from private institutions of higher education that serve an oligarchy of wealthy members of society (but are perhaps supported by public funds), to public systems geared toward socioeducational mobility and inclusion. This approach is helpful for comparing different national pathways and path dependencies that shape the development of higher education and, to some extent, inform every analysis in our field. 
Tobias Schulze-Cleven and Jennifer Olson present the results of their comparative crossnational research on how capitalist tendencies differ in forms and outcomes across the higher education sectors of the US, Germany, and Norway. These three countries were chosen as typical representatives of types of welfare capitalism, each with different levels of welfare state generosity and distinct foci of public provision. In this article, the US stands in for "liberal" countries with traditions of pro-market regulation, Germany is invoked as a representative of "conservative" countries, i.e., those which have long allowed for social groups to self-regulate, and the authors discuss Norway as an example of "social democratic" countries, those with a tradition of strong, progressive state intervention (Esping-Andersen 1990). The authors build upon recent political science theorizing on contrasting trajectories of market-making institutional changes during the past two decades and explore how higher education in all three countries has experienced liberalization. Showing outcomes to be strongly path-dependent, the article contrasts varieties of academic capitalism that mirror differences in the organization and dynamics of the countries' broader economies (Hall and Soskice 2001).

Heinz-Dieter Meyer and Kai Zhou, in turn, focus solely on higher education in the US and specifically on the role of "in-perpetuity" endowments in sustaining "winner-take-all" (Frank and Cook 1995) dynamics in the sector. The article demonstrates how endowments at top private institutions have ballooned. In the process, they have moved away from serving as the foundation of independence for organizations exercising global leadership in research and teaching and instead have morphed into an instrument for the reproduction of the upper class and a mechanism to tap into public support for sheltering the money of the rich. As Meyer and Zhou demonstrate, winner-take-all dynamics in the sector's markets strongly shape such dynamics in society more broadly. Yet, there is nothing natural about the concentration of market returns, and policy changes have strongly contributed to their rise. In concluding their analysis, the authors discuss potential political strategies that could change the situation, suggesting that if contemporary trends remain unaltered, they threaten to link US higher education inextricably to a social oligarchy.

In contrast to the perspective of public and social policy analyses, distributional conflicts can also be viewed in more structuralist and functionalist ways. Inspired by Marxist and Weberian theorizing on patterns of exploitation and domination, a number of authors understand the contemporary trend toward stratification as a characteristic (and oddly feudal) feature of the emerging system of knowledge capitalism. Following broader theories of this constellation, they are interested not only in academic stratification but also in general dynamics of exploitation, profit orientation, and class struggle within the knowledge economy (Jessop 2007; Hardt and Negri 2009). Marxists in particular are interested in the devices used to economize knowledge, which has more characteristics of a public good than of a private one (Stiglitz 1999). Infrastructures and hierarchies that help to appropriate this good might be increasingly needed in, and partly provided by, changing academic contexts.

Bob Jessop's article probes market dynamics through three thought experiments that explore different ways to understand the concept of academic capitalism. Jessop first spells out what an academic system would look like if it were thoroughly dominated by economization, marketization, and financialization. His analysis offers distinctions between mere cost-efficiency and more "capitalist" phenomena, such as the "quasi-commodification" of mental labor or the financialization of revenues in the student loan market. Jessop's two other thought experiments can be read as correctives to visions of academic capitalism that rely 
all too centrally on such ideas. He suggests that even if universities do not become for-profit enterprises, they can still be entrepreneurial in the Schumpeterian sense, giving birth to creative destruction or disruptive innovations. Moreover, he stresses that even where market forces cannot rule alone, there remains scope for a "political capitalism" with strong ties between the state and wealthy institutions.

Tilman Reitz's contribution proposes a radical revision of the idea of academic capitalism. According to Reitz, the capitalist knowledge economy requires a non-capitalist sector that can define knowledge as valuable, and the diverse mechanisms of evaluation in the academy help to provide this service. They not only facilitate the "internal" distribution of resources, but they also offer guidance for "external" actors - employers, governments, students, donors, civil society organizations - who search for expertise, intellectual reputation, sources of innovation, and promising sites for investment. Reitz concedes that academic performance measurement is only partly, and inexactly, translated into signals for the broader knowledge economy. Yet, as his analysis clarifies, the search for such signals is ongoing because intellectual property rights alone cannot sufficiently ensure the profitable use of knowledge. When knowledge behaves as a public good (i.e., non-rival in use and only artificially limited in access), there emerges an additional need to organize the distribution of cognitive resources and to ascribe status to knowledge work. It is this function that may make academic (e)valuations and hierarchies indispensable and "neo-feudal."

Finally, Oliver Wieczorek, Stefanie Beyer, and Richard Münch argue that hierarchies in academic research itself represent neo-feudalism. The authors argue that there is a general tendency for academic competition to engender oligopolistic structures, which in turn deepen the gap between autonomous and applied research at elite and non-elite institutions. Using Weberian ideal types to capture the mechanisms and forms of social closure in question, they propose a distinction between two kinds of academic neo-feudalism: "fief feudalism" with a relative autonomy of the vassals as the recipients of research grants offered by the lords, and "benefice feudalism" with clear directives of economic applicability. As the authors demonstrate empirically in an analysis of US chemistry departments, differences between both types include various dimensions, most importantly the time necessary to publish research in the highest-ranking journals. A quantitative analysis of the effects of successful grant applications and a qualitative analysis of self-views of scientists help to substantiate the ideal-typical construction.

\section{Discursive stratification}

The explanatory force that analyses of knowledge capitalism and feudalism offer over policyoriented accounts flows from a willingness to, at times, move beyond detailed, methodologically controlled empirical inquiry and embrace deductive - often functionalist - reasoning in the name of theoretical innovation. The group of scholars who concentrate on discursive practices and their social effects is situated between general claims and detailed empirical analysis. Some articles work with empirical linguistic material, while others pursue more theoretical goals. Yet, they all display a similar analytical attitude, sharing an interest in the creation of meaning and the struggles over dominant interpretation as a social activity within higher education. In this view, discourse does not merely reflect or represent social practices, political decisions, economic mechanisms, and powerful interests. Rather, the social practice of using "language" - i.e., texts, signs, numbers, or images - also contributes to the construction of social inequalities and hierarchies. Thus, by asking how social realities are constructed in 
discourse, these contributions view social change in higher education as inherently symbolic in character. The proliferation of scales measuring academic success, status, and reputation offers rich material to explore how political and economic decisions are dependent on symbolic structures and meanings.

Jens Maesse makes the case for discursive mechanisms in the governance of economics as a social science discipline. Displaying parallels with the analysis of US chemistry by Wieczorek et al., Maesse's "critical constructivist" analysis characterizes the construction, distribution, and transformation of cultural capital in economics as an "elitism dispositif." $\mathrm{He}$ traces the emergence of a globalized disciplinary order in which the unified evaluation of research output, the institutional concentration of material and personal resources, the sheer size of departments, and the level of cooperation within them clearly delineate who is recognized as a member of the profession's "elite" and who is pushed to the margins of academic visibility. According to Maesse, this dispositif finds its most important uses within political debate, economic power struggles, and the mass media, where consecrated economic experts serve to objectify otherwise controversial decisions and judgments. Displaying affinities with Reitz's observations on the functional benefits of the academy's competitive stratification, Maesse's thesis emphasizes that the symbolic order produced within the academy plays a crucial role outside of the sector by translating "symbolic capital" into other discursive means of power.

Roland Bloch and Alexander Mitterle use different concepts but employ a similar intellectual and empirical strategy in their analysis of advancing stratification in German higher education. According to their examination of business school rankings and the spread of graduate schools in Germany, stratification should be understood as a process (rather than a structure) that is driven by "field images" of academic institutions' vertical ordering. In the cases the authors examine, this process challenges state-determined "sectoral stratification" between more formally defined types of institutions. Bloch and Mitterle emphasize how rankings and the ascription of excellence join other structures in the field - including academic organization, resource distribution, mechanisms of competition, and evaluation - in teaching diverse actors to see who belongs to higher or lower strata. As their analysis shows, both individual and institutional actors respond to changing impressions. High-ranking business schools have become more attractive for students, and the number of graduate schools rose quickly once the country's Excellence Initiative had sanctioned such schools as symbolically privileged places.

The third analysis in this group-Julie Bouchard's contribution on higher education rankings in French mass media - switches the focus to the specific drivers behind these rankings' early successes. As Bouchard argues, media companies' strategies to establish market leadership in the sector of (higher) education met private needs to assess expensive pre-college training programs (as well as interests to advertise for such training). In tracing the marketing approaches, self-descriptions and evaluative techniques of two magazinesL'Étudiant and Le Monde de l'éducation (a spin-off of the newspaper Le Monde) - since the late 1970s, Bouchard demonstrates how these particular motivations produced a tool with strong homogenizing force. Adding to our understanding of rankings well before they became a global phenomenon, Bouchard shows how national practices projected heterogeneous institutions onto a number of identical scales of quality, and how organizations subsequently reacted to them.

Johannes Angermuller arguably advances this special issue's most encompassing discourse theoretical account of higher education as a symbolic economy. Analyzing the internal 
hierarchies of academic institutions and labor markets, he explores two aspects of scientific communication. First, he argues that active participation in higher education and research is always a "positioning practice" in which actors claim their own places and define where others belong through the usage of available social categories. Second, given that academic actors compete for salaried status positions, their symbolic locations are connected to their careers in the institutions. Angermuller traces these discursive processes by looking into systems of status categories that define academic careers in the US, the UK, France, and Germany, from graduate student to post-doc, from maître de conférences to professeur, etc. Academics negotiate such subjectivating categories in their everyday discursive practices, which are an important source of academic valuation. While Angermuller argues that academics are placed in Burton Clark's triangle of state, market, and professional oligarchies through discursive attributions and status categorizations, it remains to be seen how new dynamics of marketization change symbolic locations and underpin underlying power relations.

The contribution of Terri Kim offers another perspective on such marketization-induced changes. Kim uses the experiences of globally mobile academics to explore the tension between established national hierarchies and new market stratification. The share of transnational scholars in high-status positions has significantly risen, especially in the Englishspeaking world, and members of typically underprivileged ethnic minority groups often fare much better when they come from abroad (such as Indian scholars who moved to the UK). In other countries, foreigners still hit a glass ceiling, with South Korea being Kim's strongest example of this. Even if they are paid well, they never get to participate in academic decision making, as is indicated by a reference to "golden handcuffs" in one of Kim's interviews. To analyze such processes of integration and exclusion, and provide a hermeneutic account of the self-reflection of transnational scholars, Kim proposes the concept of "transnational identity capital." As she shows, scholars can gain a special capacity to compare different horizons of meaning as they move between different institutional and symbolic contexts.

\section{Theoretical complementarities, lines of contention, and a common comparative agenda}

Rather than representing a unified reading of the new political economy of higher education, the articles in this special issue provide complementary perspectives by focusing on different aspects of academic social relations. Readers will notice substantial theoretical disagreements between the articles, and it is important to address them in a systematic fashion. Three core issues of contention stand out:

1. Are transformations driven by political choices or by functional needs and structural constraints? It is analytically pressing to specify the scope and conditions for policy-driven change in higher education. Institutionalist analyses of policymaking point to substantial alternatives, but they also uncover strong path dependencies. In contrast, Marxists typically conceptualize political decisions as driven by general systemic needs and the day-to-day struggles of individuals. Moreover, they emphasize the relevant effects of market dynamics and class struggles outside of the academy on the politics of higher education. Lastly, discourse theorists highlight the micro-political struggles of situated text and talk, as well as antagonisms concerning the macro-level symbolic order.

2. What are the mechanisms that can explain the construction and transformation of symbolic orders? On this question, comparative policy analysis and functionalist accounts 
differ from discourse theoretical approaches. The first two approaches presuppose that the main causal factors and mechanisms driving academic competition and stratification across diverse contexts can be identified. Discourse theoretical treatments, on the other hand, tend to reject such attempts because they rely on construing a distinction between "surface" phenomena and "deeper" causes. For discourse theorists, discursive struggles for power do not reflect an underlying reality or social structure, rather they are situated in specific configurations in which social and semiotic resources are mobilized and connected to institutional constraints. These different perspectives overlap in numerous articles in this issue, including Bob Jessop's analysis, which includes "political imaginaries" of the knowledge society in his economic analysis. But the specific interplay of political decisions, competitive dynamics, and a shifting symbolic order clearly remains a crucial question for the analysis of social practices in higher education.

3. How should new hierarchies within higher education be conceptualized? While some theorists in this volume emphasize that academic hierarchies are conditioned by a history of political decisions and institutional arrangements, others stress that knowledge capitalism as a whole exerts cost and profitability pressures, which can only be met in hierarchical ways. "Sufficient" public funding for the entire academic workforce would likely be more than a private market economy could afford. Moreover, if diverse academic institutions had equal ranking, the lack of hierarchy would threaten the value of many intellectual assets and status positions. A third approach is to reflect on the perspectival nature of social knowledge and on ongoing struggles around meaning making and symbolic power in academic hierarchies.

Many contributions in this volume show that different theoretical orientations do not necessarily collide on these three core issues but can actually be fruitfully combined. Thus, Marxist accounts recognize the symbolic dimensions of academic capitalism (Jessop and Reitz), and discourse analytical approaches reflect on how unequal distributions of economic resources shape socially shared or contested meaning (Maesse, Bloch and Mitterle, and Angermuller), while comparative policy analyses question the limits of political intentionality (Schulze-Cleven and Olson).

Those differences that continue to exist between the contributions are further moderated by a joint commitment to using comparative cross-national analysis for attaining general insights. Regardless of theoretical divergences, this issue's articles share the idea that along the possible routes that higher education could take in the course of global expansion, there exists a range of principal options that lead to alternative distributional, institutional, and discursive orders. Comparing these options reveals political contingencies, as well as structural and functional rigidities, which would otherwise remain hidden. This view differs from the neo-institutionalist idea of isomorphism (e.g., Meyer 2007). In crucial dimensions, such as funding mechanisms, the strategies of welfare states or the role of professional oligarchies, we do not observe one paradigm shaping higher education globally. And in other dimensions where such paradigms can be identified - i.e., the trends toward institutional budget autonomy, competitive stratification, and homogenized standards of excellence - their functional roles within national systems differ significantly.

These basic variations can be addressed with an analytical elaboration of Lasswell's question about who gets what, when and how (Lasswell 1936/1958). This question highlights distributional conflicts, but it also promises to cast light on the symbolic devices and infrastructures that shape the specific logic and dynamic of conflicts. Two topics lend themselves as focal points for collaborative debate to explore these dynamics: 
1. Who pays for and who profits from expanding higher education? If the sector of higher education keeps growing in most countries (and if it keeps being haunted by specific problems of human service costs; Martin and Hill 2014), societies will have to shoulder massive new costs. Within this volume, the policy studies in particular show that the problem can be tackled in different ways: by directing costs to private individuals, by exploiting the academic workforce, or by increasing state subsidies (Schulze-Cleven and Olson), by renewing upperclass reproduction (Meyer, Zhou), or by promising new kinds of profits to business investors (Jessop, Reitz). At the same time, higher education profits are not distributed equally. As higher education has become an opportunity for financial investment, some actors have made profits from students' tuition as well as from the interest that students pay on their loans (Jessop, Schulze-Cleven and Olson). Businesses have pursued complex strategies to gain control over intellectual assets and expert status (Reitz), and public or philanthropic investments have been transformed into the property or productive advantages of private enterprises. It seems that particularly Marxist and welfare-statist perspectives have their work cut out for fruitful exchanges over who benefits in this knowledge economy.

2. How are decisions about the distribution of resources made and legitimated? The question of who gets what becomes contentious when large sums of public money are used to support higher education and private households feel compelled to make significant investments in terms of tuition and loans. Mechanisms for evaluation, such as quality and performance assessment, can generate legitimacy for allocation decisions by establishing standards of quality in the scientific and teaching community. In doing so, the processes of evaluating, measuring, and ranking (Bouchard, Bloch Mitterle, Maesse) are intrinsically polyvalent: they both assign status positions in the symbolic hierarchies of the academic world (Angermuller, Maesse), and they affect the amount of funding that institutional units and individual scientists receive (Wieczorek, Beyer and Münch). If the standards of excellence become globally homogenized, a unified system of stratification with a clear US leadership might develop (Maesse). But as long as national governments use different criteria and mechanisms to determine resource distribution, symbolic hierarchies and the allocation of financial means will not be systematically coordinated.

\section{Conclusion}

This special issue discusses contemporary transformations of higher education in leading Western academic systems, such as the United States, France, and Germany. While the contributions testify to a "new political economy of higher education," they debate the exact role and scope of distributional conflicts, political options, competitive mechanisms and discursive stratification. In the midst of disagreements, two claims seem to be beyond doubt. First, the new political economy of higher education is not the result of anonymous, unstoppable market forces but rather of political decisions and social practices, whose rules are not set in stone. Second, distributional conflicts in higher education extend to the way knowledge is produced and recognized in the higher education sector and in society more broadly. As the contributions show, researchers spend considerable resources to produce "visible" publications, they are involved in departments' and universities' attempts to attain prestige, and they compete for institutional positions of epistemic authority. In turn, it is the very nature of socially accepted and legitimate knowledge that is at stake in academic capitalism. The old question of the relationship between knowledge, power, and money therefore remains central to the new political economy of higher education. 
Acknowledgements The authors thank the journal's editors for their encouragement and the reviewers for their guidance. Helpful feedback on early versions of the special issue's articles was received during a workshop in Jena (March 2015) and at the International Conference of Europeanists in Paris (July 2015). We gratefully acknowledge generous financial support from the German Research Foundation (DFG), the Hans Böckler Foundation, the Körber Foundation, and the research group on post-growth societies at Friedrich Schiller University Jena.

\section{References}

American Academy of Arts \& Sciences. (2016). Public research universities. Recommitting to Lincoln's vision: an educational compact for the twenty-first century. Cambridge: American Academy of Arts \& Sciences.

Angermuller, J. (2013). How to become an academic philosopher: academic discourse as a multileveled positioning practice. Sociología Histórica, 2, 263-289.

Angermuller, J. (2015). Why there is no poststructuralism in France: the making of an intellectual generation. London: Bloomsbury.

Angermuller, J., Nonhoff, M., Herschinger, E., Macgilchrist, F., Reisigl, M., Wedl, J., Wrana, D., \& Ziem, A. (Eds.). (2014). Diskursforschung: Ein interdisziplinäres Handbuch (2 volumes). Bielefeld: Transcript.

Ball, S. J. (Ed.). (1990). Foucault and education: disciplines and knowledge. New York: Routledge.

Berman, E. P. (2012). Creating the market university: how academic science became an economic engine. Princeton: Princeton University Press.

Biagioli, M. (2002). From book censorship to academic peer review. Emergences: Journal for the Study of Media \& Composite Cultures, 12(1), 11-45.

Bourdieu, P. (1984). Homo academicus. Paris: Éditions de Minuit.

Brynjolfsson, E., \& MacAfee, A. (2014). The second machine age: work, progress, and prosperity in a time of brilliant technologies. New York: Norton.

Carnevale, A. P., \& Strohl, J. (2010). How increasing college access is increasing inequality, and what to do about it. In R. D. Kahlenberg (Ed.), Rewarding strivers: helping low-income students succeed in college (pp. 71190). New York: Century Foundation.

Cicchetti, D. V. (1991). The reliability of peer review for manuscript and grant submissions: a cross-disciplinary investigation. Behav Brain Sci, 14(1), 119-135.

Clark, B. R. (1983). The higher education system: academic organization in cross-national perspective. Berkeley: University of California Press.

Douglass, J. A. (2012). Money, politics, and the rise of for-profit higher education in the US: a story of supply, demand and the Brazilian effect. Center for Studies in Higher Education. Berkeley: University of California.

Drahos, P., \& Braithwaite, J. (2002). Information feudalism: who owns the knowledge economy? London: Earthscan.

Eaton, C., Habinek, J., Goldstein, A., Dioun, C., García Santibáñez Godoy, D., \& Osley-Thomas, R. (2016). The financialization of US higher education. Soc Econ Rev, 14(3), 507-535.

Engelen, E., Fernandez, R., \& Hendrikse, R. (2014). How finance penetrates its other: a cautionary tale on the financialization of a Dutch university. Antipode, 46(4), 1072-1091.

Espeland, W. N., \& Sauder, M. (2007). Rankings and reactivity: how public measures recreate social worlds. Am $J$ Sociol, 113(1), 1-40.

Esping-Andersen, G. (1990). The three worlds of welfare capitalism. Princeton: Princeton University Press.

Fang, F. C., Steen, R. G., \& Casadevall, A. (2012). Misconduct accounts for the majority of retracted scientific publications. Proc Natl Acad Sci U S A, 109(42), 17028-17033.

Fleck, C. (2013). The impact factor fetishism. European Journal of Sociology, 54(2), 327-356.

Frank, R. H., \& Cook, P. J. (1995). The winner-take-all society: why the few at the top get so much more than the rest of us. New York: Free Press.

Graf, A. (2015). Die Wissenschaftselite Deutschlands: Sozialprofil und Werdegänge zwischen 1945 und 2013. Campus: Frankfurt am Main.

Gumport, P. J. (Ed.). (2007). Sociology of higher education: contributions and their contexts. Baltimore: Johns Hopkins University Press.

Habermas, J. (1962/1989). The structural transformation of the public sphere: an inquiry into a category of bourgeois society. Cambridge: MIT Press.

Hall, P. A., \& Soskice, D. (Eds.). (2001). Varieties of capitalism: the institutional foundations of comparative advantage. Oxford: Oxford University Press.

Hamann, J. (2016). The visible hand of research performance assessment. High Educ. doi:10.1007/s10734-0159974-7. 
Hardt, M., \& Negri, A. (2009). Commonwealth. Cambridge: Belknap Press.

Hazelkorn, E. (2011). Rankings and the reshaping of higher education: the battle for world-class excellence. Basingstoke: Palgrave Macmillan.

Hornbostel, S., Klingsporn, B., \& von Ins, M. (2008). Messung von Forschungsleistungen -eine Vermessenheit? Alexander von Humboldt-Stiftung (ed.), Publikationsverhalten in unterschiedlichen Disziplinen: Beiträge zur Beurteilung von Forschungsleistungen (pp. 11-32). Bonn: Alexander von Humboldt-Stiftung.

Jessop, B. (2007). Knowledge as a fictitious commodity: insights and limits of a Polanyian perspective. In A. Buğra \& K. Ağartan (Eds.), Reading Karl Polanyi for the twenty-first century: market economy as political project (pp. 115-134). Basingstoke: Palgrave Macmillan.

Knorr Cetina, K. (1999). Epistemic cultures: how the sciences make knowledge. Cambridge: Harvard University Press.

Lamont, M. (2009). How professors think: inside the curious world of academic judgment. Cambridge: Harvard University Press.

Lamont, M. (2012). Toward a comparative sociology of valuation and evaluation. Annu Rev Sociol, 38, $201-221$.

Lasswell, H. (1936/1958). Politics: who gets what, when, how. New York: Meridian.

Latour, B., \& Woolgar, S. (1979). Laboratory life: the construction of scientific facts. Beverly Hills: Sage Publications.

Maesse, J. (2015). Economic experts: a discursive political economy of economics. Journal of Multicultural Discourses, 10(3), 279-305.

Maesse, J., \& Hamann, J. (2016). Die Universität als Dispositiv: Die gesellschaftstheoretische Einbettung von Bildung und Wissenschaft aus diskurstheoretischer Perspektive. Zeitschrift für Diskursforschung, 1(2016), 29-50.

Marginson, S. (2006). Rethinking the economics of education: the public/private divide in higher education. In B. S. Grewal \& M. Kumnick (Eds.), Engaging in the new world: responses to the knowledge economy (pp. 5376). Carlton: Melbourne University Press.

Marginson, S. (2008). A funny thing happened on the way to the k-economy: new world order in higher education: research rankings, outcome measures and institutional classifications. Paris: OECD.

Marginson, S., \& van der Wende, M. (2007). To rank or to be ranked: the impact of global rankings in higher education. J Stud Int Educ, 11(3-4), 306-329.

Martin, R. E., \& Hill, R. C. (2014). Baumol and Bowen cost effects in research universities. https://ssrn. com/abstract $=2153122$.

Mathies, C., \& Slaughter, S. (2013). University trustees as channels between academe and industry: toward an understanding of the executive science network. Res Policy, 42(6-7), 1286-1300.

McGettigan, A. (2013). The great university gamble: money, markets and the future of higher education. London: Pluto.

Mettler, S. (2014). Degrees of inequality: how the politics of higher education sabotaged the American dream. New York: Basic Books.

Meyer, J. W. (2007). The university in Europe and the world: twentieth century expansion. In G. Krücken \& G. S. Drori (Eds.), World society: the writings of John W. Meyer (pp. 355-371). Oxford: Oxford University Press.

Möller, C. (2015). Herkunft zählt (fast) immer: Soziale Ungleichheiten unter Universitätsprofessorinnen und professoren. Beltz Juventa: Weinheim.

Münch, R. (2013). Academic capitalism: universities in the global struggle for excellence. New York: Routledge.

Münch, R. (2016). Die Macht der Zahlen in der Evaluation wissenschaftlicher Forschung: Eine soziologische Erklärung. In J. Hamann, J. Maeße, V. Gengnagel, \& A. Hirschfeld (Eds.), Macht in Wissenschaft und Gesellschaft: Diskurs- und feldanalytische Perspektiven (pp. 215-228). Wiesbaden: Springer.

Musselin, C. (2013). How peer review empowers the academic profession and university managers: changes in relationships between the state, universities and the professoriate. Res Policy, 42(5), 1165-1173.

Neckel, S. (2013). Refeudalisierung - Systematik und Aktualität eines Begriffs der Habermas'schen Gesellschaftsanalyse. Leviathan, 41(1), 39-56.

Peters, M. A., Besley, A. C., Olssen, M., Maurer, S., \& Weber, S. (Eds.). (2009). Governmentality studies in education. Rotterdam: Sense Publishers.

Powell, W. W., Owen-Smith, J., \& Colyvas, J. A. (2007). Innovation and emulation: lessons from American universities in selling private rights to public knowledge. Minerva, 45(2), 121-142.

Reinhart, M. (2012). Soziologie und Epistemologie des Peer Review. Baden-Baden: Nomos.

Rhoades, G. S., \& Slaughter, S. (2006). Academic capitalism and the new economy: privatization as shifting the target of public subsidy in higher education. In R. A. Rhoads \& C. A. Torres (Eds.), The university, state, and market: the political economy of globalization in the Americas (pp. 103-140). Stanford: Stanford University Press.

Rhoten, D., \& Calhoun, C. (Eds.). (2011). Knowledge matters: the public mission of the research university. New York: Columbia University Press.

Rivera, L. (2015). Pedigree how elite students get elite jobs. Princeton: Princeton University Press. 
Rogge, J.C. (2015). Soziale Bedingungen und Effekte der quantitativen Leistungsmessung. Soziale Welt, 66(2), $205-214$.

Rose, N. (1996). Inventing our selves: psychology, power, and personhood. Cambridge: Cambridge University Press. Sauder, M., \& Espeland, W. N. (2009). The discipline of rankings: tight coupling and organizational change. Am Sociol Rev, 74(1), 63-82.

Schulze-Cleven, T. (2017). Higher education in the knowledge economy: politics and policies of transformation (introduction). PS: Political Science and Politics, 50(2). doi:10.1017/S1049096516002894.

Serrano-Velarde, K. (2015). Verwaltungsmodernisierung oder Bürokratisierung? Zur Einführung von Qualitätssicherung in der Hochschullehre. In H. P. Müller \& T. Reitz (Eds.), Bildung und Klassenbildung: Kritische Perspektiven auf eine Leitinstitution der Gegenwart (pp. 231-247). Weinheim: Beltz Juventa.

Slaughter, S., \& Leslie, L. L. (1997). Academic capitalism: politics, policies, and the entrepreneurial university. Baltimore: Johns Hopkins University Press.

Slaughter, S., \& Rhoades, G. S. (2004). Academic capitalism and the new economy: markets, state and higher education. Baltimore: Johns Hopkins University Press.

Stiglitz, J. (1999). Knowledge as a global public good. In I. Kaul, I. Grunberg, \& M. A. Stern (Eds.), Global public goods: international cooperation in the twenty-first century (pp. 308-325). Oxford: Oxford University Press.

Sum, N. L., \& Jessop, B. (2013). Towards a cultural political economy: putting culture in its place in political economy. Cheltenham: Edward Elgar.

Thelen, K. (2014). Varieties of liberalization and the new politics of social solidarity. New York: Cambridge University Press.

Trow, M. (1974). Problems in the transition from elite to mass higher education. In OECD (Ed.), Policies for higher education (pp. 51-101). Paris: OECD.

Zinn, K.-G. (2015). Vom Kapitalismus ohne Wachstum zur Marktwirtschaft ohne Kapitalismus. Hamburg: VSA. 